WARSZTATY Z GEOGRAFII TURYZMU

ISBN 978-83-7525-925-4 $\quad$ s. 307-320

http://dx.doi.org/10.18778/7525-925-4.21

Danuta ŻYLAK

Akademia Wychowania Fizycznego w Katowicach

Szkoła Główna Gospodarstwa Wiejskiego w Warszawie

\title{
SZKODY NIEMAJĄTKOWE I ICH KOMPENSACJA W PRZYPADKU BANKRUCTWA TOUROPERATORA
}

\section{Wstęp}

Podczas sezonu letniego 2012 r. ogłoszonych zostało kilkanaście upadłości organizatorów turystyki skutkujących ograniczeniem zaufania do podmiotów sektora turystycznego.

W Centralnej Ewidencji Organizatorów i Pośredników Turystycznych zarejestrowanych jest 3558 podmiotów (www.turystyka.gov.pl; 2013) prowadzących działalność w różnych formach organizacyjno-prawnych, w większości funkcjonujących jako przedsiębiorstwa mikro bądź małe. Ogromna konkurencja w branży nie wpływa znacząco na ograniczenie liczby działających przedsiębiorstw. Wielość tych podmiotów sprawia, iż zaostrza się walka konkurencyjna poprzez prześciganie się w oferowaniu zachęcających warunków zakupu imprez turystycznych. Zaistniała sytuacja pokazała, jakim ryzykiem obarczona jest działalność na rynku turystycznym.

Konsumenci usług turystycznych powinni być odpowiednio chronieni przed nieuczciwymi i nierzetelnymi działaniami podmiotów, z którymi zawierają umowy o imprezę turystyczną. Niestety często nie znają oni proce- 
dur związanych ze złożeniem ewentualnej reklamacji, dotyczącej nienależytego wykonania warunków umowy o imprezę turystyczna, jak również procedur w przypadku ogłoszenia upadłości przez biuro podróży.

Zgodnie z danymi Urzędu Ochrony Konkurencji i Konsumentów i TNS Polska (www.tur-info.pl,2012), większość turystów nie ma świadomości, w jaki sposób dochodzić swoich praw w odniesieniu do nieudanego urlopu. Dane te pokazują jak mała liczba turystów (7\%) wie, ile ma czasu na złożenie reklamacji dotyczącej nienależytego wykonania umowy. Zaledwie 17\% turystów potrafi sprawdzić legalność funkcjonowania danego biura podróży. Niestety 57\% turystów nie czyta zawieranych umów o imprezę turystyczną.

Celem autorki opracowania jest dokonanie analizy możliwości ewentualnej kompensacji szkód niemajątkowych, powstałych w momencie bankructwa organizatora turystyki.

\section{Rodzaje szkód oraz ich kompensacja}

Każdy uszczerbek w mieniu, prawach lub osobie, którego doznała osoba poszkodowana (tak fizyczna, prawna, jak i jednostka organizacyjna), który powstał w wyniku zdarzenia objętego ochroną ubezpieczeniową w ramach zawartej umowy jest szkodą. Powstanie szkody wywołuje pojawienie się roszczenia ubezpieczeniowego, a więc roszczenia o świadczenie ubezpieczeniowe (KOWALEWSKI 2002). Definicja szkody, którą przyjmuje się w umowie ma decydujący wpływ na określenie zakresu odpowiedzialności ubezpieczyciela. Zależy ona bowiem ściśle od postanowień umownych, które mogą stanowić, że pewne rodzaje, wielkości szkody będą wyłączone z zakresu ochrony (RONKA-CHMIELOWIEC 2002).

Szkoda może mieć postać (RONKA-CHMIELOWIEC 2002):

- osobową która jest konsekwencją naruszenia dóbr osobistych (zdrowie, integralność cielesna, psychika); może także wyrażać się w konsekwencjach majątkowych;

- majątkową dotyczącą bezpośrednio składników majątkowych.

Szkoda, jako uszczerbek o charakterze majątkowym może przyjmować postać:

- straty rzeczywistej (utraty aktywów lub przyrostu pasywów); 
- utraconych korzyści - które osoba poszkodowana mogłaby osiągnąć, gdyby nie powstała szkoda; korzyści te jednak muszą być realne, a nie hipotetyczne (utrata szansy na uzyskanie korzyści).

W rozumieniu odpowiedzialności cywilnej szkoda jest określona przede wszystkim jako uszczerbek majątkowy lub niemajątkowy (art. 361 k.c., Dz.U. z 1964 r., nr 16, poz. 93 z późn. zm.)ํ.

Szkody dzielą się na trzy grupy:

- szkody z tytułu tzw. czynów niedozwolonych, dotyczące odpowiedzialności deliktowej (art. 415-449 k.c.);

- szkody z tytułu odpowiedzialności kontraktowej (art. 471 i n. k.c.);

- szkody z tytułu odpowiedzialności wynikającej z umów (NOWAKOWSKI 2004).

Pod ogólnym pojęciem szkody rozumie się szkodę majątkową i niemajątkową (krzywdę).

Szkoda majątkowa wiąże się z wszelkim uszczerbkiem majątkowym, jakiego doznaje dobro poszkodowanego. Natomiast uszczerbek niemajątkowy nazywany jest krzywdą (NOWAKOWSKI 2004). Szkodę niemajątkową można określić jako naruszenie dóbr osobistych i interesów poszkodowanego przy jednoczesnym nie uszczupleniu jego majątku. Uszczerbku niemajątkowego nie da się wycenić w sposób obiektywny i wyczerpujący (NOWAKOWSKI 2004).

Rodzaje roszczeń odszkodowawczych, które przysługują podmiotom poszkodowanym uzależnione są od rodzaju ryzyka i zakresu udzielanej ochrony ubezpieczeniowej w ramach zawartej umowy i z reguły mają charakter:

- roszczeń majątkowych;

- roszczeń osobowych (MONKIEWICZ 2004).

Odszkodowanie ubezpieczeniowe (świadczenie) jest wypłatą kwoty wynikającej z umowy ubezpieczenia, do której ubezpieczyciel jest zobowiązany w przypadku zajścia zdarzenia losowego określonego w umowie.

Świadczenie ubezpieczyciela polega w szczególności na zapłacie:

- określonego odszkodowania za szkodę powstałą wskutek przewidzianego w umowie wypadku $\mathrm{w}$ odniesieniu do ubezpieczeń majątkowych;

${ }^{1}$ Art. 361 k.c. $\S 1$. Zobowiązany do odszkodowania ponosi odpowiedzialność tylko za normalne następstwa działania lub zaniechania, z którego szkoda wynikła. § 2 . W powyższych granicach, braku odmiennego zapisu ustawy lub postanowienia umowy, naprawienie szkody obejmuje straty, które poszkodowany poniósł oraz korzyści, które mógłby osiągnąć, gdyby mu szkody nie wyrządzono. 
- umówionej sumy pieniężnej, renty lub innego świadczenia w przypadku zajścia przewidzianego w umowie wypadku w życiu osoby ubezpieczonej przy ubezpieczeniach osobowych (art. $805 \S 2$ k.c., Dz.U. z 1964 r., nr 16, poz. 93 z późń. zm.).

W odniesieniu do szkody niemajątkowej (krzywda), będącej uszczerbkiem niemającym odzwierciedlenia w majątku osoby poszkodowanej używa się terminu "zadośćuczynienie” zamiast pojęcia „odszkodowanie”.

Istnieje również specjalny rodzaj roszczenia odszkodowawczego zwany regresem ubezpieczeniowym, zgłaszanym przez ubezpieczyciela do sprawcy powstałej szkody. Mechanizm ten polega na wejściu ubezpieczyciela, który pokrył szkodę wyrządzoną poszkodowanemu (będącego jednocześnie ubezpieczonym) w pozycję prawną poszkodowanego w stosunku do sprawcy (KOWALEWSKI 2002).

Podstawową pozycję w rachunku finansowym ubezpieczycieli stanowią wydatki związane z zaspokajaniem roszczeń ubezpieczeniowych. Pochłaniają one znaczną (60-70\%) część składki w ubezpieczeniach majątkowych, dlatego też profesjonalna organizacja całego procesu oraz właściwe kompetencje służb ubezpieczycieli mają fundamentalne znaczenie dla rentowności działalności ubezpieczeniowej (MONKIEWICZ 2004).

Obsługa roszczeń jest z natury procesem konfliktogennym oraz podatnym na zjawiska hazardu moralnego i przestępczości ubezpieczeniowej, bowiem zakład ubezpieczeń dąży do minimalizacji wypłacanych odszkodowań i świadczeń, a ubezpieczony, uposażony czy poszkodowany oczekuje maksymalnej satysfakcji finansowej.

Proces zarządzania likwidacją szkód jest bardzo zróżnicowany w zależności od rodzaju ubezpieczenia (MONKIEWICZ 2004).

\section{Bezpieczeństwo turysty}

Prowadzenie działalności gospodarczej polegającej na organizowaniu imprez turystycznych oraz pośredniczeniu na zlecenie klientów w zawieraniu umów o świadczenie usług turystycznych staje się możliwe po spełnieniu warunków określonych w przepisach szczególnych i uzyskaniu wpisu w rejestrze działalności regulowanej. 
Podstawą prawną przedsiębiorczości w turystyce jest Ustawa o ustugach turystycznych (Dz.U. z 1997 r., nr 133, poz. 884 z późn. zm.) wraz z przepisami wykonawczymi i Rozporzadzenie Ministra Gospodarki z dnia 13 czerwca 2001 r. w sprawie centralnego rejestru zezwoleń (Dz.U. z 2001 r., nr 62, poz. 633 z późn. zm.) nakłada obowiązek prowadzenia rejestru przez ministra właściwego do spraw turystyki. Wpisu do rejestru dokonuje się na podstawie ostatecznej decyzji Marszałka Województwa (Dz.U. z 2005 r., nr 175, poz. 1462 z późn. zm.). Celem prowadzenia rejestru jest ułatwienie potencjalnemu konsumentowi usług turystycznych uzyskania m.in. informacji o posiadaniu przez przedsiębiorstwo turystyczne stosownego zabezpieczenia turystycznego, wymaganego ustawowo w przypadku organizatora bądź pośrednika turystycznego. Dostęp do Centralnej Ewidencji Organizatorów Turystyki i Pośredników Turystycznych umożliwia stałe monitorowanie działań podejmowanych przez przedsiębiorców, ujawniając legalność ich funkcjonowania. W Centralnej Ewidencji Organizatorów i Pośredników Turystycznych (dawniej: Centralny Rejestr Zezwoleń) zarejestrowanych jest obecnie (stan na 08.05.2013 r.) 3558 podmiotów (www.turystyka.gov.pl/raporty).

W turystyce warunkiem niezbędnym, narzuconym przez ustawodawcę, do uzyskania wpisu do Centralnej Ewidencji Organizatorów i Pośredników Turystycznych jest zabezpieczenie klientów w razie niewypłacalności tych podmiotów. Następuje to poprzez zawarcie umowy ubezpieczenia lub gwarancji ubezpieczeniowej lub gwarancji bankowej na okres 12 miesięcy z zastrzeżeniem konieczności odnawiania na kolejne lata prowadzenia działalności, jak i przedkładania oryginałów wznowionych dokumentów właściwemu organowi na 14 dni przed upływem terminu ważności poprzednich dokumentów. Mamy więc do czynienia z bezwzględnie wymaganym przez prawo turystyczne koniecznym ubezpieczeniem, warunkującym uruchomienie i prowadzenie działalności gospodarczej w turystyce.

Na gruncie prawa wspólnotowego sytuację bezpieczeństwa turysty normuje art. 7 Dyrektywy Rady z dnia 13 czerwca 1990 r. w sprawie zorganizowanych podróży, wakacji i wycieczek (Dz.U. WE nr 158/59, 23.06 .1990 r., s. 132-137) świadczonych $w$ formie kombinacji usług turystycznych za cenę zryczałtowaną.

Organizator i/lub punkt sprzedaży detalicznej jako strona umowy powinien zapewnić dostateczne zabezpieczenie zwrotu nadpłaconych pieniędzy i powrotu konsumenta z podróży na wypadek swojej niewypłacalności (Dz.U. WE nr 158/59, 23.06.1990 r., s. 136). 
Dyrektywa ta zezwala państwom członkowskim dokonać wyboru własnego systemu zabezpieczenia. Przed przyjęciem Dyrektywy w Danii, Holandii, Irlandii i Wielkiej Brytanii stworzono Fundusz Gwarancyjny chroniący konsumenta na wypadek niewypłacalności organizatora (GWOźDZICKA-PIOTROWSKA 2007). Państwa członkowskie Unii Europejskiej przyjęły jeden z poniższych sposobów implementacji Dyrektywy 90/314/EWG:

- stworzenie funduszu gwarancyjnego,

- przyjęcie obowiązkowego ubezpieczenia lub

- powyższe rozwiązania jako alternatywa (decyzję pozostawiono branży turystycznej).

W większości państw Wspólnoty wprowadzono instytucje funduszy gwarancyjnych lub obowiązkowych ubezpieczeń, warunkując dodatkowo podjęcie działalności w zakresie usług turystycznych uzyskaniem odpowiedniego zezwolenia lub licencji.

W Polsce implementacja wymienionej Dyrektywy nastąpiła ustawą o usługach turystycznych.

Dyrektywa unijna nie działa w sposób bezpośredni na państwa członkowskie, a jedynie zmusza je do dostosowania prawa krajowego do jej zasad. Nadmienić należy, iż Dyrektywa 90/314/EWG ma charakter minimalny, co oznacza dosyć dużą dowolność przy nadawaniu ostatecznego kształtu prawa w Polsce („Wiadomości Turystyczne” z 30.08.2012 r.).

Zagadnienie dotyczące odpowiedzialności organizatora lub pośrednika turystycznego za niewykonanie zobowiązań wynikających z umowy z konsumentem zostało uregulowane w art. 5 Dyrektywy 90/314/EWG. W odniesieniu do wymienionego artykułu państwa członkowskie mają zagwarantować odpowiedzialność organizatora lub pośrednika turystycznego za szkodę wyrządzoną w wyniku niewykonania lub nienależytego wykonania umowy. Regulacja powyższa znalazła odzwierciedlenie w art. 11a ustawy o usługach turystycznych (Dz.U. z 1997 r., nr 133, poz. 884 z późn. zm.).

W systemach prawnych państw członkowskich kwestia dochodzenia zadośćuczynienia nie jest jednolita. Niektóre systemy pozostawiły tę kwestię w gestii sądów. W prawie polskim przyjęto zasadę, iż zadośćuczynienie za szkodę niemajątkową należy się wyłącznie, gdy przewiduje to ustawa, która aktualnie jednoznacznie nie dopuszcza przyznania zadośćuczynienia z tytułu niewykonania umowy. Przełomem dla systemów prawnych było orzeczenie Trybunału Sprawiedliwości UE w sprawie Simone Leitner v. TUI Deutschland GmbH\&CoKG (sygn.akt: C-168/00) z dnia 12 marca 2002 r., 
nakazujące prawo do kompensacji zarówno strat materialnych, jak i niematerialnych w odniesieniu do art. 5 Dyrektywy 90/314/EWG.

Artykuł ten nie różnicuje pojęcia szkody na materialną i niematerialną $\mathrm{w}$ odniesieniu do konsumentów usług turystycznych w zakresie odszkodowania za utratę przyjemności z podróży i „zmarnowany urlop”.

\section{Udany wypoczynek jako zaspokojenie turystycznych potrzeb człowieka}

Potrzeba jest stanem pożądania czegoś, który wywołuje stan napięcia. Odczucie to można zredukować poprzez zaspokojenie potrzeby lub jej wyciszenie. Zaspokojenie następuje zwykle poprzez nabycie lub użytkowanie dóbr. Proces zaspokajania konkretnych potrzeb może być bardzo zróżnicowany. Z hierarchii potrzeb A.H. Maslowa wynika, że potrzeby turystyczne należą do grupy potrzeb rozwoju jednostki - grupy potrzeb wyższych (RUDNICKI 2010). Powszechnie wiadomo, że podróże poszerzają horyzonty poprzez poznawanie nowych miejsc, kultur czy nawiązywanie znajomości. Wakacje, podczas których wypoczywa się lub podejmuje różnego rodzaju zajęcia rekreacyjne, realizuje własne pasje, mają stymulujący wpływ na umysł człowieka. Podróże wiążą się także z potrzebami estetycznymi. Wyrazem tego są tłumy turystów obserwujących zachód słońca, podziwiających ogrom gór czy kaskady wodospadów (ZDEBSKI 1996). Podróżowanie, którego istotną częścią są podróże turystyczne, może zaspokajać potrzeby człowieka na wszystkich poziomach. Różne potrzeby mogą być realizowane poprzez rozmaite podróże, choć najczęściej w trakcie jednej podróży udaje się zaspokoić kilka potrzeb (KACZMAREK, STASIAK, WŁODARCZYK 2005).

Każdy ma więc prawo do udanego wypoczynku.

Sezon wakacyjny (maj-wrzesień 2012 r.) obfitował w upadki biur podróży, co pociągnęło za sobą odwołane loty, pozostawionych w ośrodkach na świecie pechowych turystów, zablokowane dokonywanie płatności kartami kredytowymi za usługi turystyczne, jak również turystów, którym nie udało się zrealizować zaplanowanego i opłaconego wypoczynku.

W tab. 1 zamieszczonej poniżej zaprezentowano zestawienie organizatorów turystyki, którzy ogłosili upadłość i jednocześnie pozostawili poszkodowanych klientów w wakacyjnych kurortach. 
Tabela 1. Ogłoszone upadłości organizatorów turystyki w 2012 r.

\begin{tabular}{|l|l|l|r|}
\hline $\begin{array}{c}\text { Data } \\
\text { upadłości }\end{array}$ & \multicolumn{1}{|c|}{ Nazwa podmiotu } & \multicolumn{1}{|c|}{ Ubezpieczyciel } & $\begin{array}{c}\text { Liczba osób poszko- } \\
\text { dowanych, pozostawionych } \\
\text { za granicą }\end{array}$ \\
\hline 20.05 .2012 & Excalibur Tours & Signal Iduna Polska T.U S.A & 38 \\
\hline 03.07 .2012 & Sky-Club Sp.zo.o & T.U.Europa S.A. & 4700 \\
\hline 13.07 .2013 & Alba-Tour Sp.zo.o & T.U.Europa S.A. & 430 \\
\hline 16.07 .2012 & Aficano Travel Sp.zo.o & AXA TUiR S.A. & 190 \\
\hline 26.07 .2012 & Blue-Rays Sp.zo.o & T.U.Europa S.A. & 360 \\
\hline 27.07 .2012 & B.P.Atena & TUW & 52 \\
\hline 30.07 .2012 & Elektra Travel & AXA TUiR S.A. & 0 \\
\hline 03.08 .2012 & Aquamaris S.A. & T.U.Europa S.A. & 600 \\
\hline 09.08 .2012 & Mati World Holidays Sp.zo.o & Signal Iduna Polska T.U S.A. & 185 \\
\hline 11.08 .2012 & Oriac Polska Sp.zo.o & T.U.Europa S.A. & 526 \\
\hline 27.08 .2012 & B.T.Watra S.c. & AXA TUiR S.A. & 0 \\
\hline 04.09 .2012 & Filiz Travel & Signal Iduna Polska T.U S.A. & 2 \\
\hline 11.09 .2012 & 5 Stars Club Business Travel & Signal Iduna Polska T.U S.A. & 0 \\
\hline
\end{tabular}

Źródło: opracowanie własne na podstawie informacji pozyskanych ze stron internetowych www.tur. info.pl, www.rp.pl oraz poszczególnych Urzędów Marszałkowskich.

Upadłości te pokazały, że klienci biur podróży nie są objęci wystarczającą ochroną $w$ przypadku niewypłacalności organizatora turystyki. Praktyka pokazała, że posiadane przez wymienione podmioty zabezpieczenia finansowe są niewystarczające na pokrycie wszystkich wierzytelności. Dyrektywa 90/314/EWG w tym względzie jest wyraźna i ma już bogate orzecznictwo ETS, z którego wynika, iż państwo członkowskie powinno gwarantować klientom zwrot tzw. przedpłat w pełnej wysokości. Nie pojawiły się natomiast orzeczenia, w sprawie odpowiedzialności z tytułu „zmarnowanego urlopu". Jeżeli tego nie robi, ponosi odpowiedzialność odszkodowawczą wobec poszkodowanego. Jest to odpowiedzialność za nieprawidłowe wprowadzenie dyrektywy unijnej, która przyznaje klientowi konkretne uprawnienie (CYBULA 2012).

Osoby poszkodowane na skutek bankructwa organizatora turystyki nie są bezradne, mają kilka możliwości rekompensaty szkody, ale muszą liczyć się ze stratami (ZIMMERMAN 2012).

Ogłoszenie niewypłacalności organizatora turystyki oznacza dla jego wierzycieli konieczność poniesienia strat. Konsumenci usług turystycznych należą do grupy uprzywilejowanej, bowiem podlegają ochronie, jaką gwarantuje im zabezpieczenie finansowe organizatora turystyki. Organem 
uprawnionym do uruchomienia środków z zabezpieczenia finansowego jest Marszałek Województwa odpowiedni w odniesieniu do siedziby przedsiębiorcy. Na witrynach internetowych Urzędów Marszałkowskich osoby poszkodowane mogą znaleźć formularze zgłoszenia roszczenia z turystycznej gwarancji ubezpieczeniowej. Nieprzekraczalny termin składania roszczeń dotyczących niezrealizowanych lub przerwanych imprez turystycznych dla klientów, którzy zawarli umowy w okresie obowiązywania zabezpieczenia finansowego upływa po 365 dniach. W pierwszej kolejności z tego zabezpieczenia wykorzystuje się środki na pokrycie kosztów sprowadzenia do kraju turystów przebywających poza jego granicami. W dalszej kolejności zwracane są środki tym osobom, które nie rozpoczęły wypoczynku, a uregulowały całość należności bądź wpłaciły zaliczkę. Z zabezpieczenia finansowego organizatora, który ogłosił upadłość pozostałe po pokryciu kosztów sprowadzenia turystów do kraju środki zostają rozdzielone pomiędzy wszystkich, którzy zapłacili całość lub część należności za imprezę turystyczna proporcjonalnie do wpłaconej kwoty. To zabezpieczenie finansowe $\mathrm{w}$ postaci gwarancji ubezpieczeniowej lub bankowej, lub ubezpieczenia nie obejmuje pokrycia strat za powstałe szkody niemajątkowe w postaci zmarnowanego (przerwanego czy nierozpoczętego) urlopu. W tej kwestii o odpowiedzialności mówią przepisy ustawy o usługach turystycznych. Podstawę prawną roszczeń o szkodę majątkową i niemajątkową stanowi art. 11a wymienionej ustawy.

Organizator turystyki odpowiada za niewykonanie lub nienależyte wykonanie umowy o świadczenie usług turystycznych. Natomiast podstawę prawną żądania odpowiedzialności za szkodę niemajątkową stanowią art. 23 i art. 24 kodeksu cywilnego. Sąd Najwyższy w wyroku z 24.03.2011 r. (sygn. akt. I CSK 372/10) stwierdził, iż naruszenie przez biuro podróży TUI Poland prawa turysty do udanego urlopu jest naruszeniem jego dóbr osobistych. Tym samym poszerzono otwarty katalog dóbr osobistych wskazany tylko przykładowo w art. 23 k.c. o prawo do wypoczynku (http://lex.pl, 27.08. 2012). Sąd Najwyższy stwierdził w swoim orzeczeniu, że niewłaściwe wykonanie umowy o usługi turystyczne daje prawo do odszkodowania i zadośćuczynienia. Wskazał również na konieczność brania pod uwagę orzecznictwa Trybunału Sprawiedliwości Unii Europejskiej w Luksemburgu przez sądy krajowe Dyrektywy 90/314/EWG, która nakazuje uwzględniać straty materialne i niematerialne wczasowiczów, spowodowane złym wykonaniem umowy. Dyrektywę tę Trybunał Sprawiedliwości zastosował, przyznając 
prawo do odszkodowania za utratę przyjemności z podróży i zmarnowany urlop.

Skoro Trybunał Sprawiedliwości, w orzeczeniu z dnia 12.03.2002 r. orzekł, że art. 5 Dyrektywy 90/314/EWG powinien być wykładany w sposób obejmujący pojęciem szkody także uszczerbek niemajątkowy w postaci „zmarnowanego urlopu", to art. 11a ustawy o usługach turystycznych przenoszący art. 5 dyrektywy do polskiego porządku prawnego, musi być wykładany w ten sam sposób (http://www.kancelariaclj.pl, 27.08.2012).

Szkoda w rozumieniu uchwały Sądu Najwyższego z dnia 19.11.2010 r. (sygn. akt. III CZP 79/10) powstała wskutek „zmarnowania urlopu” ma charakter niemajątkowy, za co klient ma prawo żądać odpowiedniego zadośćuczynienia. Szkoda ta niewątpliwie ma charakter niemajątkowy, bowiem:

- polega na utracie oczekiwanych $\mathrm{w}$ związku $\mathrm{z}$ zawarciem umowy o imprezę turystyczną przyjemnych przeżyć związanych z podróżą wypoczynkiem i oddawania się realizacji własnych pasji;

- taka przyjemność pozostaje w związku z podróżą; nieuzyskana przez niewykonanie lub nienależyte wykonanie zapisów umowy pozostaje wyłącznie w sferze marzeń i uczuć, z tego też powodu jest zjawiskiem czysto psychicznym, pozbawionym elementu majątkowego czy komercyjnego ( http://blog-e-prawnik.pl, 27.08.2012).

Wycena szkody niemajątkowej jest oczywistym problemem. Wobec braku możliwości odniesienia się do ceny rynkowej naruszonego dobra znaczenie mogą mieć kwoty dotychczas przyznawane przez sądy. Tendencje jednak zmieniają się i przyznawane są coraz większe sumy tytułem zadośćuczynienia. Orzecznictwo w sprawie kompensacji za „zmarnowany urlop" dopiero zacznie się kształtować, co naraża pokrzywdzonych na nieodpowiednie oszacowanie roszczenia (WOŁOsZCZAK 2012).

Pomocna przy szacowaniu wysokości odszkodowania może być również tzw. tabela frankfurcka (www.konsument.gov.pl,27.08.2012) - nieoficjalny dokument stworzony na zlecenie Izby Cywilnej Sądu Krajowego w Niemczech na potrzeby rozstrzygania sporów dotyczących niewykonania umowy przez organizatora turystyki. Coraz częściej stosowany przez biura podróży w Polsce przy rozpatrywaniu reklamacji, ponieważ zawiera katalog nieprawidłowości wraz z propozycją procentowego obniżenia ceny imprezy turystycznej lub poszczególnej usługi w razie, gdy niedotrzymane zostały warunki umowy (JEZIORSKA 2009). 
W przypadku ogłoszenia bankructwa przez organizatora turystyki, gdzie zakupiona została impreza turystyczna, klient może skorzystać, oprócz złożenia roszczenia do właściwego Urzędu Marszałkowskiego, ze zgłoszenia wierzytelności w postępowaniu upadłościowym, by móc być traktowany na równi z innymi wierzycielami, takimi jak: hotele, przewoźnicy, choć w tym przypadku nie można się spodziewać odzyskania znaczących sum pieniędzy. W tym jednak momencie klient może doliczyć oprócz kwot utraconych także roszczenia odszkodowawcze. Upadłość, z której klient nie otrzyma pełnej kompensacji swoich szkód, daje mu prawo do dochodzenia wierzytelności niezapłaconych przez syndyka bezpośrednio od członków zarządu upadłej spółki (ZIMMERMAN 2012).

W przypadku dokonania płatności kartą płatniczą poszkodowani klienci mogą skorzystać w banku, który wydał kartę, z usługi tzw. obciążenia zwrotnego (ang. chargeback). Usługa ta pozwala odzyskać środki w przypadku niedostarczenia towaru bądź usługi. Dochodzenie swoich praw możliwe jest w odniesieniu do wszystkich rodzajów kart (kredytowych, debetowych, charge oraz przedpłaconych). Reklamację z tego tytułu zobowiązany jest przyjąć każdy bank, wydający karty działających na polskim rynku organizacji płatniczych. W procedurę obciążenia zwrotnego zaangażowani są: klient, wydawca karty, organizacja płatnicza, agent rozliczeniowy oraz akceptant karty (np. biuro podróży). Upadłość biura podróży jest sytuacją nietypowa ponieważ wiadomo, że dana usługa (impreza turystyczna) nie zostanie zrealizowana. Klienci powinni być przygotowani na zastrzeżenia ze strony banku, bowiem muszą one zaangażować wiele instytucji równocześnie, dlatego też upowszechnianie usługi chargeback nie leży w interesie banków, organizacji płatniczych. Klient musi podjąć stanowcze kroki wobec banku, ponieważ jest to prawdopodobnie najskuteczniejsza metoda odzyskania całości kwoty wpłaconej touroperatorowi (MIELNIK 2012).

Część podmiotów, które ogłosiły bankructwo oferowała swoje produkty poprzez serwisy zakupów grupowych (Groupon, Gruper). W momencie upadłości serwisy te dokładały wszelkich starań, by ograniczyć przykre doświadczenia tym klientom, którzy skorzystali z ich ofert, poprzez dokonanie zamiany na imprezę innego organizatora lub dokonanie zwrotu wpłaconej kwoty. Z chwilą przekazania pieniędzy usługodawcy serwisy te nie są zobligowane do zwrotu wcześniej wpłaconych kwot, jednak fala upadków spowodowała, że podjęto decyzję o ich wypłacie w pełnych kwotach. Można 
zauważyć, że takie wydarzenia mogą mieć negatywny wpływ zarówno na kondycję finansową serwisów zakupowych, jak i na ich wizerunek.

Bankructwa te pokazały, że zakup imprezy turystycznej po niskiej cenie (obniżki nawet do $80 \%$ ) obarczony jest ryzykiem. Z możliwości oferowania swoich produktów poprzez serwisy zakupów grupowych największe biura podróży nie korzystały, z kolei dla małych podmiotów był to nowy sposób dotarcia do dużej liczby odbiorców (MAZURKIEWICZ 2012).

Zła sytuacja organizatorów turystyki nie jest tylko wynikiem obecnego sezonu wakacyjnego, ale konsekwencją wcześniejszych zdarzeń (erupcja wulkanu na Islandii, zamieszki w krajach Afryki Północnej czy kryzys w Grecji, Hiszpanii i we Włoszech), a także utratą płynności finansowej.

Najwyższa Izba Kontroli opublikowała informację o wynikach kontroli dotyczącej przestrzegania warunków świadczenia usług turystycznych (www.nik.gov.pl,18.04.2013), poddając kontroli realizację zadań przez Ministra Sportu i Turystyki, Prezesa Urzędu Ochrony Konkurencji i Konsumentów oraz marszałków województw. Ocena ta wykazała, że działania Ministra Sportu i Turystyki w zakresie tworzenia mechanizmów prawnych dotyczących zabezpieczeń finansowych na rzecz klientów usług turystycznych nie były wystarczające (www.nik.gov.pl,18.04.2013).

\section{Wnioski}

Podsumowując można powiedzieć, że dopuszczalne jest dochodzenie zadośćuczynienia za krzywdę z uwagi na tzw. „zmarnowany urlop”, a podstawą roszczenia jest artykuł 11a ustawy o usługach turystycznych. Jest to element poczucia bezpieczeństwa przez turystę i stanowi generalną podstawę dochodzenia roszczeń o zadośćuczynienie, związanych z niewykonaniem lub nienależytym wykonaniem zapisów umowy o imprezę turystyczną $\mathrm{z}$ touroperatorem.

Konsumenci usług turystycznych mogą dochodzić swoich roszczeń na zasadach ogólnych, dotyczących roszczeń cywilnoprawnych na podstawie przepisów Kodeksu cywilnego.

Natomiast w przypadku bankructwa organizatora turystyki poszkodowani klienci mają 365 dni na złożenie roszczenia z tytułu posiadanego przez ten podmiot zabezpieczenia finansowego do właściwego Urzędu Marszał- 
kowskiego. W tym przypadku nie mogą domagać się rekompensaty/zadośćuczynienia za utraconą możliwość zaspokojenia potrzeby wypoczynku. Mają jednak możliwość zgłoszenia roszczeń w ramach postępowania upadłościowego.

Wydarzenia letniego sezonu w 2012 r. uwypukliły problem braku odczuwalnej poprawy sytuacji, bezpieczeństwa konsumentów usług turystycznych po wprowadzonej w 2010 r. nowelizacji ustawy o usługach turystycznych. Widać wyraźnie, iż cel ustawodawcy nie został osiągnięty, bowiem pojawiły się przypadki niewystarczających zabezpieczeń nawet na sprowadzenie klientów do kraju. W tych przypadkach marszałkowie województw zmuszeni byli uruchomić środki własne na sprowadzenie turystów biur podróży, które ogłosiły upadłość.

Ministerstwo Sportu i Turystyki przygotowało projekt utworzenia Turystycznego Funduszu Gwarancyjnego, będący aktualnie w fazie konsultacji społecznych. Natomiast Ministerstwo Finansów w dniu 22.04.2013 r. opublikowało w Dzienniku Ustaw nowe Rozporzadzenie w sprawie obowiazkowego ubezpieczenia na rzecz klientów wymaganego w zwiazku z działalnościa wykonywana przez organizatorów i pośredników turystycznych (Dz.U. z 2013 r., nr 0, poz. 510) oraz Rozporządzenie dotyczące minimalnej wysokości sumy gwarancji bankowej lub ubezpieczeniowej (Dz.U., 2013 r., nr 0, poz. 511), które weszły w życie 14.05.2013 r.

Wśród najważniejszych zmian znalazło się: zwiększenie sum gwarancji, wprowadzenie nowego sposobu ich naliczania - na podstawie dochodu deklarowanego, oraz konieczność dokonania zmiany sum gwarancyjnych w trakcie roku, jeśli organizator przekroczy zadeklarowany wcześniej dochód.

\section{BIBLIOGRAFIA}

CYBULA P., 2012, Gwarancje zbyt stabo chroniq turystów, opinia „Rzeczpospolita” 11.07.

GWOŹDZICKA-PIOTROWSKA M., 2012, Obowiazek zapewnienia bezpieczeństwa i ochrona konsumenta w przypadku upadłości biura podróży na tle dyrektywy turystycznej i jej wdrożeń, http:// seminarium.21.edu.pl/ks/3/596 (22.08.2012).

JEZIERSKA A., 2009, Gdy klient reklamuje wycieczkę, "Rynek Turystyczny” 3.

Kaczmarek J., Stasiak A., WŁodarczYK B., 2005, Produkt turystyczny, PWE, Warszawa, s. 139140.

KOWALEWSKI E., 2002, Umowa ubezpieczeniowa, Oficyna Wydawnicza Branta, Bydgoszcz-Toruń, ss. 112. 
MAZURKIEWICZ P., 2012, Bankructwa biur podróży mogq szkodzić serwisom zakupów grupowych, „Rzeczpospolita” 09.08.

MIELNIK S., 2012, Jak odzyskać pieniąze z biura podróży, http://www.ekonomia24.pl/artykul/ 911725.html (22.08.2012).

MonkieWICZ J., 2004, Podstawy ubezpieczeń, t. III: Przedsiębiorstwo, Wydawnictwo Poltext, Warszawa.

NOWAKOWSKi L., 2004, Ubezpieczenia odpowiedzialności cywilnej, Poltext, Warszawa, s. 29-30.

RONKA-CHMielowiec W., 2002, Ubezpieczenia. Rynek i ryzyko, PWE, Warszawa, ss. 59.

RUDNICKI L., 2010, Zachowania konsumentów na rynku turystycznym, Proksenia, ss. 22.

„Wiadomości Turystyczne” (30.08.2012).

WoŁoszczaK W., 2012, Kancelaria Prawna Piszcz, Norek i Wspólnicy, www.piszcz.pl/pliki/Jakieza dośćuczynieniedla turysty-09_08_2012_11_00.pdf (09.08.2012).

ZDEBSKI J., 1996, Elementy psychologii turystyki, [w:] Pilotaż wycieczek zagranicznych, P.U-SZ. Mentor, Kraków, ss. 83.

ZIMMERMAN P., 2012, Jak odzyskać pieniadze od upadtego touroperatora, „Rzeczpospolita” 6.07. 2012.

Dz.U. z 1964 r., nr 16, poz. 93.

Dz.U. z 1997 r., nr 133, poz. 884.

Dz.U. z 2010 r., nr 106, poz. 672.

Dz.U. z 2001 r., nr 62, poz. 633.

Dz.U. z 2005 r., nr 175, poz. 1462.

Dz.U z 2013 r., nr 0, poz. 511.

Dz.U.WE nr 158/59, 23.06.1990 r., s. 132-133.

http://www.tur-info.pl// (04.07.2012).

http://lex.pl/czytaj/-/artykul/zamarnowany-urlop--8211 (27.08.2012).

http://www.kacelariaclj.pl/artykul/biura-podrozy-zaplaca-odszkodo... (27.08.2012).

http://blog-e-prawnik.pl/zadoscuczynienie-za-zmarnowany-urlop.html (27.08.2012).

http://www.nik.gov.pl/aktualnosci/nik-o-biurach-podrozy-2013.html (18.04.2013).

www.konsument.gov.pl/files/t.frankfurcka.pdf ( 27.08.2012).

www.turystyka.gov.pl/raporty (12.09.2012). 